\title{
The influence of the deep seated geological structures on the landscape morphology of the Dunajec River catchment area, Central Carpathians, Poland and Slovakia
}

\author{
Bartosz Wołosiewicz
}

Faculty of Geology, Geophysics and Environment Protection, AGH University of Science and Technology, Al. Mickiewicza 30, 30-059 Kraków, Poland

* corresponding author: bartek.wolosiewicz@gmail.com

Received: $10^{\text {th }}$ April, 2017

Accepted: $28^{\text {th }}$ February, 2018

\begin{abstract}
The area of the Dunajec river basin includes several geological units in the Central Carpathian region at the Polish-Slovakian borderland. The paper focuses on the geomorphometric parameters of the drainage system to recognize the influence of the deep seated geological structures on the morphology of the Dunajec river basin (Central Carpathians). The study were enriched with analysis of the geological maps and lineaments extracted from Digital Elevation Model. According to the obtained results, the massive NW-SE trending fault zones play a vital role in the geological architecture of the researched area. The development of the secondary fault structures has been determined by these dislocations and the manifestation of their activity can be observed as deformations of some of the other tectonic structures along the main fault zones, especially at the folds' axes. Additionally, the geometric and morphometric features of the drainage system have also been influenced by the activity of these deep structures.

The tectonic activity represented by the level of morphological rejuvenation, visible in the light of the morphometric parameters of the streams and the drainage basins, varies greatly between the tectonic units. This diversity is caused by both the lithological and structural features of these geological units.
\end{abstract}

Key words: morphotectonics, morphometry, DEM, base-levels, hypsometry, Central Carpathians

\section{Introduction}

The Central Carpathians are known as one of the most tectonically active areas in Poland. The Dunajec drainage basin belongs to the two major seismic regions (Beskid Sądecki Region and Pieniny \& Podhale Region; Schenk et al., 2001; Guterch, 2009).

Recent tectonic activity in the Central Carpathians was corroborated using numerous methods. According to Makowska and Jaroszewski (1987), who have analyzed the results of precise leveling performed in the Polish Carpathians in 1933, 1954 and 1974, the Tatra Mts. have uplifted in relation to the
Podhale zone. The area as a whole has uplifted in relation to the Outer Carpathians. The rates of the uplift in the Polish Carpathians varies from $0.001 \mathrm{~mm}$ per year in the Outer Carpathians to $0.105 \mathrm{~mm}$ per year in the Tatra Mts. (Zuchiewicz, 1999). According to Makowska and Jaroszewski (1987), the rate of the uplift can even reach up to $0.4 \mathrm{~mm}$ per year in the Tatra Mts. The maps of absolute speed of the vertical movement of Earth's crust have been developed on the basis of the leveling data (e.g. Wyrzykowski, 1971; Fig.1).

The structural studies performed by numerous authors (e.g Mastella et al., 1996; 
2012; Szczygiel, 2015) allowed to reconstruct the contemporary stress fields.

Many authors report numerous locations with fractured clasts in Pleistocene gravels within the Podhale area (e.g. Tokarski and Zuchiewicz, 1998; Ahmed and Świerczewska, 2013), which also indicates the contemporary activity of the area.

Dendrochronology is another method used lately to investigate the neo-tectonic activity within the research area. Some studies (e.g. Michałowicz et. al., 2014) suggest the influence of earthquakes on the landslides activity in Podhale area. The trees present at the epicenters of earthquakes which were observed in the Carpathians are characterized by specific traumatic micro- and macrofeatures such as vertical cracks and injuries, tree ring reductions and eccentricity, reaction wood and resin canals.

The morphometric parameters of streams and drainage basins chosen for this study are very good indicators illustrating the relationship between a drainage system and the activity associated with vertical uplifting (e.g. Horton, 1945; Smith, 1950; Miller, 1953; Schumm, 1954; Chorley, 1971; Bull, 1977; 1978; Bull and McFadden, 1977; Zuchiewicz, 1999; 2010; Brzezińska-Wójcik, 2010; Matos et al. 2014). They are proven to deliver reliable data about the surface deformations in significantly seismically active areas such as the Himalayas (Burbnak, 1992; Kirby and Whipple, 2001), the Hindu Kush (Mahmood and Gloaguen, 2002), Northern California (Lifton and Chase, 1992; Snyder et al., 2000) or Mexico (Gaidzik and Ramirez-Herra, 2016). Thus, they are commonly used to investigate the mountainous areas around the world (e.g. Frankel and Pazzaglia, 2005; Badura et al., 2007; Bull, 2007).

The main goal of this study is to recognize the influence of the deep seated geological structures on the morphology of the terrain surface in the researched area.
The Dunajec river basin covers an area of $6804 \mathrm{~km}^{2}$ at the Polish-Slovakian borderland, within the Central Carpathians and includes both the Internides (Inner Carpathians) and the Externides (Outer, flysch Carpathians). The river itself is $274 \mathrm{~km}$ long and it originates in the Tatra Mts. as the Czarny Dunajec. The Dunajec forms a $27 \mathrm{~km}$ - long border between Poland and Slovakia in the Pieniny range, east of Lake Czorsztyn (Reservoir). The Dunajec runs across various geological units and structures which makes its morphology a useful indicator of geological developments.

\section{Study area}

The Dunajec drainage basin is located almost entirely within the Carpathian Mountains. The range stretches from Austria, to the Iron Gate, on the Danube in Romania (Golonka et al., 2005, 2011). It contains various tectonic units and lithological types (Żelaźniewicz et al., 2011). This diversity has been caused by the dynamic geological history of the Carpathian range (Jurewicz, 2005), as well as, by current tectonic activity (Zuchiewicz, 2010). Traditionally, the Carpathians are subdivided into their western and eastern parts. The West Carpathians include the older, internal orogenic zone known as the Inner or Central Carpathians, and the external, younger one, known as the Outer or Flysch Carpathians (e.g. Mahel', 1974; Ślączka and Kaminski, 1998). The Inner Carpathians were folded during the Late Cretaceous period and are now in a tectonic contact with the Outer Carpathian units across a transform fault zone represented by the Pieniny Klippen Belt (Golonka et al., 2005).

The study area includes the Polish fragment of the Inner Carpathians; the Tatra Mountains and the Podhale Basin. The Tatra Mts., where the Dunajec River takes source are the highest mountain range of the Carpathians. They form an elevated, asymmetric horst, tilted northward that is cut off from the south by a 
major Neogene-Quaternary normal fault and is surrounded by sediments of the Central Carpathian Paleogene (Jurewicz, 2005). The igneous and metamorphic rocks of the Tatra crystalline core are cropping out in its southern part. This fragment of the Inner Carpathian Paleozoic basement consists of the Variscan polygenetic granitoid intrusion and the preVariscan to the Variscan metamorphic envelope. The autochthonous Mesozoic sedimentary rocks have been deposited on the rocks of the crystalline massif which are overlain by several allochthonous thrust sheets and small nappes. The Tatric, Križna and Choč nappes can are over thrusted on autochthonous units. All of these units are discordantly covered with a post-nappe, transgressive succession of the Central Carpathian Paleogene Basin and mainly the flysch sediments are exposed in the Podhale Basin sinclinorium located between the the Tatra Mountains and the Pieniny Klippen Belt. The uplift of the Tatra Mts., dated using apatite fission tracks, took part probably during the Miocene (15-10 Ma). This process continued until the Holocene period due to the uneven uplift of the Tatra Mts. exposing both the crystalline core and Mesozoic cover (; Burchart, 1972; Jurewicz, 2005;). The morphology was finally shaped by four Pleistocene glaciation events. One of such significant morphological forma are the ridgetop trenches (double crest forms), known from the Western Tatras, are supposed to be the structures related to the neo-tectonic morphological processes (e.g. Jaroszewski, 1965; Alexandrowicz and Alexandrowicz, 1988; Kromuszczyńska and Mege, 2014; Pánek et al., 2015). Longitudinal recesses along the ridges and crests are common and similar trenches can also occur on the highly inclined slopes. They can be up to 100 meters long and several meters deep and are typically located within the areas built of crystalline and metamorphic rocks.
The Pieniny Mountains are a part of the Pieniny Klippen Belt - the suture zone between the Outer and Inner Carpathians (Jurewicz, 2005; Fig.1). The "Klippen" (term introduced by Neumayr, 1871) are relatively erosion-resistant mainly carbonate blocks surrounded by and rising above the less competent rocks, mainly flysch, shales, and marls. Numerous klippes (klippen) build scenic rocks around the Dunajec River Gorge (Krobicki and Golonka, 2008). The Pieniny Mountains are built mainly by carbonate rocks so the karstological forms are very common (Birkenmajer, 1965).

The present day confines of the suture zone of the Pieniny Klippen Belt are regarded as strictly tectonic and are characterized as subvertical faults and shear zones which form the complex flower structure. Both strike slip and thrust components occur within the Polish section of the Pieniny Klippen Belt (e.g. Jurewicz, 2005; Golonka et al, 2005, 2015). Within the Pieniny Klippen Belt the tectonic components of different age, strike-slip faults, thrusts as well as toe-thrusts and olistostromes are mixed together, giving the present-day mélange character of this belt where individual units are hard to distinguish. The Paleogene andesite intrusions are also present in this area. The volcanic arc was created during the Miocene period along the northern border of the Pieniny Klippen Belt. The sill intrusions (first phase andesites), related to the faults, are parallel to the PKB and were created first while the perpendicular faults were used later by the andesite magma creating multiple dykes (second phase andesites; Birkenmajer, 2003; Fig.1).

The Dunajec Gorge runs through the Pieniny Mountains and it is related to the Dunajec fault zone (Jurewicz, 2005). The valleys of the Dunajec River's tributaries, the Czarny Dunajec, the Biały Dunajec, and the Białka River are related to the deep seated fault structures, as well (Fig.1). 


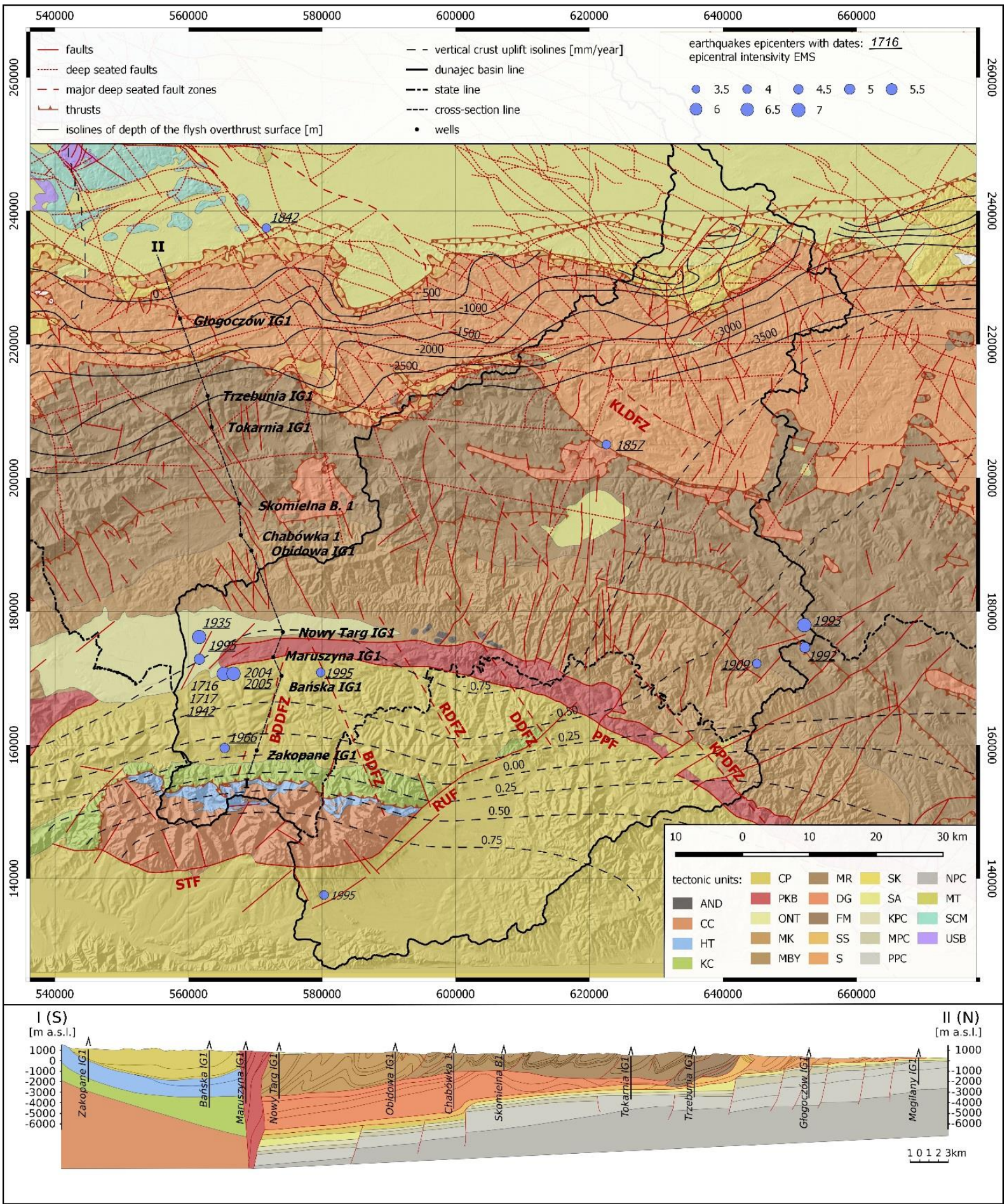

Fig.1. Tectonic sketch map and profile (compiled from various authors, e.g.: Zuchiewicz, 1981; Wyrzykowski, 1985; Buła and Kotas, 1994; Jurewicz, 2005; Buła and Habryn, 2008; Żelaźniewicz et al., 2011; Mastella et al, 2012): BDDFZ - Biały Dunajec Deep Fault Zone; BDFZ - Białka Deep Fault Zone; RDFZ - Rijeka Deep Fault Zone; DDFZ - Dunajec Deep Fault Zone; KPDFZ - Kraków-Prešov Deep Fault Zone; KLDFZ - KrakówLubliniec Deep Fault Zone; PPF - Peri Pieniny Fault; RUF - Ružbachy Fault; AND - andesites; CC - Crystaline Massif of the Tatra Mts.; HT - High Tatra units; KC - Krizna and Choc Nappes; CP - Central Carpathian Paleogene Sediments; PKB - Pieniny Klippen Belt; ONT - Orava-Nowy Targ Basin; Magura Nappe: MK Krynica Unit; MBY - Bystrica Unit; MR - Raca and Siary Units; DG - Dukla and Grybów Units; FM Foremagura Nappe; SS - Sub-Silesian Nappe; S - Silesian Nappe; SK - Skole Unit; 
Fig.1. continued: SA - Kenozoic cover of the Outer Carpathians Basement; MPC - Mesozoic cover of the Outer Carpathians Basement; PPC - Paleozoic cover of the Outer Carpathians Basement; NPC - Neoproterozoic rocks below the Paleozoic cover; CB - Outer Carpathians basement.

The northern part of the research area is occupied by the Beskidy Mts. belonging to the Outer Carpathians. The Outer Carpathians are built up of a stack of nappes and thrust-sheets showing a different lithostratigraphy and tectonic structures. The Outer Carpathians nappes are thrust upon each other and on the North European Platform as well as its Miocene-Paleocene cover. (Golonka et al., 2011, Krobicki et al., 2012).

The Outer Carpathians are built of the Upper Jurassic-Neogene flysch sediments imbricated due to thrusting. Those relatively unresisting flysch rocks, which are acted upon by the specific hydrological conditions and the neo-tectonic and seismic activity are the reason for common mass movements occurances (e.g. Rączkowski, 2007).

The Carpathians thrusts (nappes) became detached from the basement during the overthrusting movement and only their basinal parts were preserved. The following Outer Carpathian nappes have been distinguished: Magura Nappe, Fore-Magura group of nappes, Silesian and Subsilesian nappes (Golonka et al., 2009; 2011).

The seismic revealed that the Carpathian nappes are cut by major strike-slip faults. Some of these faults are local and some of them form huge systems which can reach over one hundred kilometers in length and affect all of the outer Carpathian nappes, the Pieniny Klippen Belt, and the Inner Carpathians. The Skawa river fault zone, perfectly visible in the seismic profiles, is perpendicular to the strike of the Outer Carpathian thrust sheets(cytat jakiś). The displacement of the nappes of the Carpathian overthrust and the diapiric extrusion of the plastic formations of the lower flysch units occurred along this fault, which constitutes fragments of the major ViennaKrakow fault zone. Another major fault zone is known as the Kraków-Prešov fault (Żaba 1995; 1999). It is an extension of the subsequent mutual strike-slip displacements of the two blocks along the Kraków-Lubliniec Fault Zone (Golonka et al., 2009; 2011). Both of the faults distinguish the border zone between the East European Craton (represented by the Małopolska Block) and the Brunovistulicum Terrain (represented by the Upper Silesia Block; Żaba, 1995; Buła and Habryn, 2008). They intersect the research area in its NE part. However, their impact on the morphology of the area is restricted by the fact that they belong to the deep, Sub-Carpathian, Paleozoic complex overlaid by the younger Mesozoic complex as well as the Carpathian nappes (Buła et al., 1997; Żaba, 1999; Buła, 2000).

There are also two major sub-longitudinal regional scale faults within the researched area: The Sub-Tatric fault at the southern front of the Tatra Mts. and the Peri-Pieniny Fault, parallel to the Pieniny Klippen Belt (e.g. Jurewicz, 2005).

The thrust-folding in the Tatra Mts. and within the Pieniny Klippen Belt was controlled by the strike-slip shear zone. It caused the counter-clockwise rotation of the Tatra Block because of the Miocene subduction and the subsequent collision of the North-European continental crust with the Central Carpathian Block, deep fault zones have been activated (Jurewicz, 2005). The Orava Basin originated as an intramontane depression during the Neogene times. The rotation of Inner Carpathian Plate and strike-slip movement led to the development of the pull-apart basin.

The morphostructural character of the Carpathians is a product of the Tertiary evolution, finalized by the Neogene (Neoalpine) collisional events, which imprinted the present-day shape to the Carpathian orogenic belt. Acceleration of the 
ocean floor spreading in the Atlantic Ocean was the engine of the Alpine orogenesis and led to the convergence of the Afro-Arabian lithospheric plate including its promontory and the North European plate. The space between these two megablocks where Apulia and Alcapa were located was broken up into several translating and rotating microplates, reflecting squeezing caused by northward propagation of the African plate. Within the structure of the Carpathian tectogene, several typical distinct morphotectonic features can be distinguished, such as; the arc-shaped orogenic belt, core mountains alternating with intramontane basins, well-developed Miocene volcanic arc, structures generated by intraorogen rotations, the Pieniny Klippen Belt structure, fan-like structures, and intra-orogen bending. All of these phenomena are believed to be the products of the youngest, Neogene (Neoalpine) tectonic period. Faulting played a tremendous role during the Neogene tectonic evolution. The dense and regular fault network is one of the characteristic features of the Carpathians. Brittle faults, mainly strike-slip ones, in combination with other dynamic tectonic boundaries, allowed for propagation of individual detached blocks to the realm of the Carpathian region (Golonka et al., 2005).

\section{Materials and methods}

\section{Hydrographic data}

The source of the hydrographic data is the Hydrographic Map of Poland (MPHP). The cartographic materials of the MPHP were obtained from themaps at a scale of 1:50000, in the coordinate system "1942" and supplemented with data from the field.

\section{Digital Elevation Model}

The Digital Elevation Model (DEM), used in this study, is based on the Digital Terrain Elevation Database level 2 (DTED 2). DTED 2 was constructed by the Geographic Survey of the Polish Army in 1999. The model was developed on the basis of the topographic map 1:50,000, coordinate system "WGS-84". Grid cell size $1 \times 1$ and $1 \times 2$ arc-second, approx. $30 \mathrm{~m}$ side-length (courtesy of ZGW WOGiT 2000).

\section{Slope aspect and lineaments analysis}

The slope aspect map was based on the DETD2 model using the Aspect tool from the Quantum GIS Terrain analysis toolbox. The raster was utilized with the simple filter, which allowed to reduce the systematic errors caused by the numerical derivation over a rectangular grid (Jordan, 2003). All of the statistical analyses were performed for slopes with an inclination of more than $2^{\circ}$, so the plains were excluded (Fig.2A). Then, the rose diagram of the slope aspect was drawn (Fig.2B).

Lineaments (according to Hobbs, 1904) are "significant lines of landscape which reveal the hidden architecture of rock basement". This kind of analysis is widely used as an easy method of remote sensing in geoscience. However, there are a lot of controversies about the reliability of this method. Particularly, the process of lineaments extraction seems to be quite subjective.

The lineaments were delineated based on the multiple images developed on the basis of the DETD2 model - shaded relief maps with various settings of insolation angle and azimuth, as well as, the aspect map. The interpretations have been performed based on two sets of maps at scales of 1:100000 and 1:500000 to present the structures of various orders (Fig.2C). The orientation diagrams have been constructed, which allowed to compare the geometry of the morphological and geological features (Fig.2D).

\section{Morphometric analysis of streams}

The analysis of the morphometric indices of the drainage systems allows to detect recent tectonic activity and uplifting as river channels are very sensitive to changes in the parameters that control their shape and gradient (e.g.: Doranti-Tiritan et al., 2014). Rivers tend to 
develop equilibrium profiles over relatively short time spans. Consequently, any deviation of the longitudinal stream profile from the stream equilibrium suggests the presence of a resistant channel bed rock or tectonic activity along the course (e.g.: Rãdoane et al., 2003; Korup, 2006; Pérez-Peña et al., 2010; DorantiTiritan et al., 2014). Concave profiles are supposed to represent long-term equilibrium balance between climatic conditions, uplift rate, and erosional processes (Matoš et al., 2014). More "concave-convex", S-shaped longitudinal profiles, are typical for the areas where the erosional processes prevail while convex profiles occur in tectonically active areas or in highly resistant channel bedrock (Pérez-Peña et al., 2010; Matoš et al., 2014).

In this study, the analysis of the normalized longitudinal stream profiles allowed for comparison of the parameters of 50 streams with different lengths and absolute elevation gradients (Matoš et al. 2014; Fig.3). For this purpose, the distance values along the streams were normalized to the total length of the streams $(/ / L)$, and elevation values to the absolute elevation gradients along the streams ( $h / H$; Demoulin, 1998; Ruszkiczay-Rüdiger et al., 2009; Matoš et al., 2014). Concavity factor $\left(C_{f}\right)$, maximum concavity $\left(C_{\max }\right)$ and the distance from the source $(d l / L)$ have been calculated to estimate the differences between the streams and the equilibrium profile (Fig.4A-E).

The concavity factor corresponds to the plot area between the normalized stream profile and the straight line drawn from the stream source to the mouth of the stream and can be expressed as a percentage of the plot area. The Cmax parameter represents the normalized maximal elevation difference between the stream profile and the ideal straight line connecting the source point and the mouth of the stream.

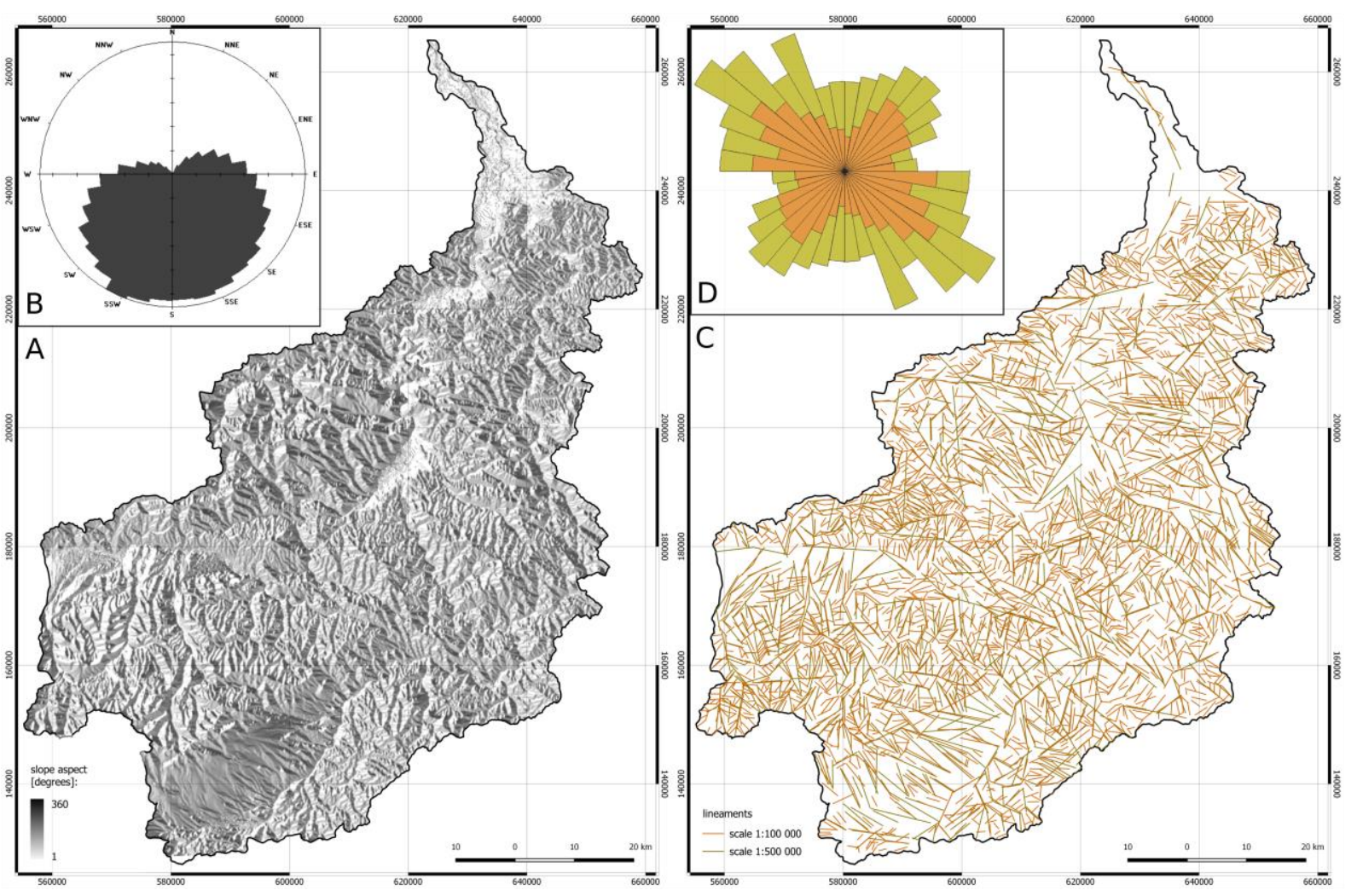

Fig.2. Slope aspect and lineaments analyses: A - slope aspect raster map; B - slope aspect rose diagram; C lineaments map; D - lineaments rose diagram: orange - scale 1:100 000; green - scale 1:500 000 . 


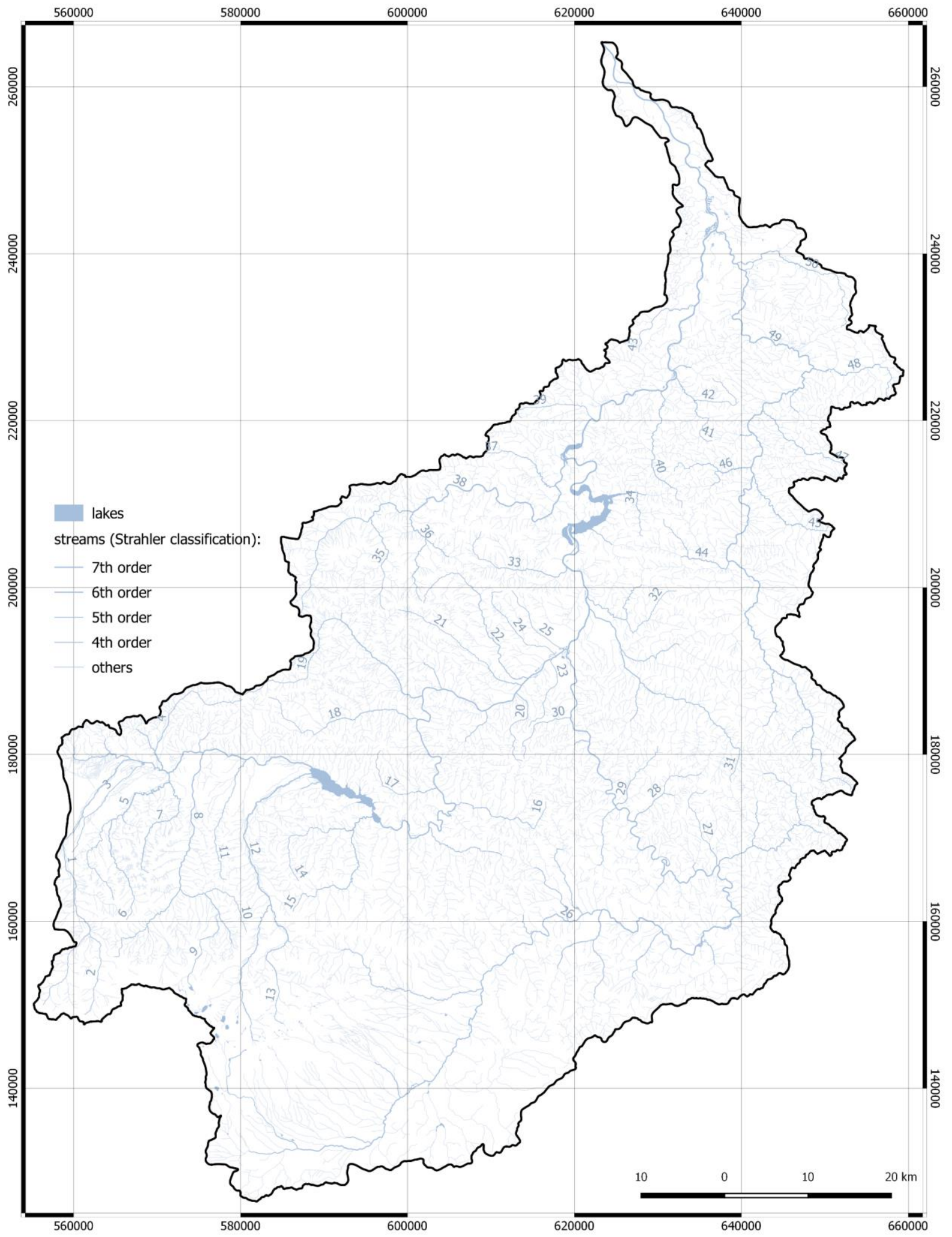

Fig.3. Hydrographic sketch map. For details see Table 1. 
Tab.1. The values of $H_{\min }, H_{\max }, H_{\text {mean }}, C_{\max }, d l / L$ and $C_{f}$ calculated for 50 streams within the researched area (see Fig. 3).

\begin{tabular}{|c|c|c|c|c|c|c|c|c|}
\hline \multirow[b]{2}{*}{ lp. } & \multirow[b]{2}{*}{ Name of the stream } & \multirow[b]{2}{*}{ Stream order } & \multicolumn{3}{|c|}{ Elevation } & \multicolumn{3}{|c|}{ Concavity } \\
\hline & & & $\begin{array}{c}\text { Hmax } \\
\text { (source) }\end{array}$ & $\begin{array}{c}\text { Hmin } \\
\text { (mouth) }\end{array}$ & Hmean & $\begin{array}{c}\text { Maximal } \\
\text { Concavity } \\
\text { Cmax }\end{array}$ & $\begin{array}{l}\text { Distance } \\
\text { from the } \\
\text { source } \\
\mathrm{d} 1 / \mathrm{L}\end{array}$ & $\begin{array}{l}\text { Concavity } \\
\text { factor } \mathrm{Cf}\end{array}$ \\
\hline 1 & Czarny Dunajec & IV & 1486.00 & 582.00 & 785.47 & 0.43 & 0.23 & 27.49 \\
\hline 2 & Kirowa Woda & III or less & 1537.00 & 879.00 & 1055.31 & 0.40 & 0.25 & 23.21 \\
\hline 3 & Czarny & III or less & 754.00 & 611.00 & 672.00 & 0.10 & 0.43 & 7.34 \\
\hline 4 & Lepietnica & III or less & 1251.00 & 602.00 & 768.65 & 0.40 & 0.21 & 24.32 \\
\hline 5 & Wielki Rogoźnik & $\mathrm{V}$ & 869.00 & 596.00 & 673.08 & 0.36 & 0.29 & 21.77 \\
\hline 6 & Bystry & IV & 1102.00 & 644.00 & 779.00 & 0.33 & 0.21 & 20.52 \\
\hline 7 & Maly Rogoźnik & IV & 978.00 & 600.00 & 708.71 & 0.35 & 0.37 & 21.24 \\
\hline 8 & Biały Dunajec & $\mathrm{V}$ & 1178.00 & 580.00 & 738.18 & 0.43 & 0.09 & 23.55 \\
\hline 9 & Cicha Woda & IV & 1623.00 & 779.00 & 1075.13 & 0.27 & 0.53 & 14.91 \\
\hline 10 & Poroniec & III or less & 1059.00 & 730.00 & 852.86 & 0.18 & 0.47 & 12.66 \\
\hline 11 & Leśnica & IV & 937.00 & 561.00 & 696.60 & 0.24 & 0.39 & 13.94 \\
\hline 12 & Białka & $\mathrm{V}$ & 2282.00 & 523.00 & 860.80 & 0.53 & 0.16 & 30.80 \\
\hline 13 & Jaworowy Potok & IV & 1890.00 & 818.00 & 1113.68 & 0.38 & 0.27 & 22.42 \\
\hline 14 & Łapszanka & IV & 926.00 & 518.00 & 664.69 & 0.23 & 0.33 & 14.05 \\
\hline 15 & Niedziczanka & $\mathrm{V}$ & 984.00 & 481.00 & 644.39 & 0.27 & 0.32 & 17.52 \\
\hline 16 & Grajcarek & IV & 942.00 & 436.00 & 606.56 & 0.28 & 0.27 & 16.29 \\
\hline 17 & Krośnica & IV & 1028.00 & 415.00 & 599.00 & 0.35 & 0.25 & 19.98 \\
\hline 18 & Ochotnica & IV & 1231.00 & 383.00 & 638.08 & 0.33 & 0.26 & 19.92 \\
\hline 19 & Kamienica Zabrzeska & $\mathrm{V}$ & 1131.00 & 370.00 & 649.94 & 0.22 & 0.33 & 13.21 \\
\hline 20 & Jaworzynka & IV & 873.00 & 325.00 & 528.00 & 0.17 & 0.55 & 12.96 \\
\hline 21 & Jastrząbka & IV & 700.00 & 314.00 & 478.47 & 0.11 & 0.63 & 7.39 \\
\hline 22 & Słomka & IV & 791.00 & 313.00 & 449.35 & 0.35 & 0.20 & 21.48 \\
\hline 23 & Moszczenica & III or less & 478.00 & 302.00 & 359.45 & 0.28 & 0.40 & 17.36 \\
\hline 24 & Gostwiczanka & III or less & 595.00 & 299.00 & 400.36 & 0.23 & 0.31 & 15.76 \\
\hline 25 & Brzeźnianka & III or less & 625.00 & 294.00 & 401.45 & 0.29 & 0.30 & 17.54 \\
\hline 26 & Poprad & VI & 1925.00 & 294.00 & 570.80 & 0.62 & 0.11 & 33.03 \\
\hline 27 & Szczawnik & IV & 915.00 & 444.00 & 641.33 & 0.12 & 0.58 & 8.10 \\
\hline 28 & Wierchomlanka & IV & 796.00 & 408.00 & 569.27 & 0.10 & 0.55 & 8.43 \\
\hline 29 & Łomniczanka & IV & 851.00 & 378.00 & 547.30 & 0.20 & 0.40 & 14.21 \\
\hline 30 & Przysietnicki Potok & III or less & 800.00 & 326.00 & 500.60 & 0.17 & 0.39 & 13.16 \\
\hline 31 & Kamienica Zabrzeska & $\mathrm{V}$ & 828.00 & 279.00 & 447.18 & 0.31 & 0.24 & 19.37 \\
\hline 32 & Łubinka & IV & 464.00 & 276.00 & 335.47 & 0.31 & 0.36 & 18.37 \\
\hline 33 & Smolnik & IV & 788.00 & 269.00 & 389.65 & 0.46 & 0.19 & 26.75 \\
\hline 34 & Przydonianka & $\mathrm{V}$ & 479.00 & 265.00 & 320.64 & 0.39 & 0.30 & 24.00 \\
\hline
\end{tabular}


Tab.1. continued:

\begin{tabular}{|c|c|c|c|c|c|c|c|c|}
\hline \multirow[b]{2}{*}{ lp. } & \multirow[b]{2}{*}{ Name of the stream } & \multirow[b]{2}{*}{ Stream order } & \multicolumn{3}{|c|}{ Elevation } & \multicolumn{3}{|c|}{ Concavity } \\
\hline & & & $\begin{array}{c}\text { Hmax } \\
\text { (source) }\end{array}$ & $\begin{array}{l}\text { Hmin } \\
\text { (mouth) }\end{array}$ & Hmean & $\begin{array}{c}\text { Maximal } \\
\text { Concavity } \\
\text { Cmax }\end{array}$ & $\begin{array}{c}\text { Distance } \\
\text { from the } \\
\text { source } \\
\text { dl/L }\end{array}$ & $\begin{array}{l}\text { Concavity } \\
\text { factor Cf }\end{array}$ \\
\hline 35 & Slopniczanka & IV & 730.00 & 391.00 & 496.31 & 0.37 & 0.31 & 18.94 \\
\hline 36 & Sowlinka & IV & 740.00 & 351.00 & 457.14 & 0.39 & 0.14 & 22.71 \\
\hline 37 & Białka & IV & 477.00 & 245.00 & 303.50 & 0.46 & 0.25 & 24.78 \\
\hline 38 & Łososina & VI & 946.00 & 236.00 & 374.14 & 0.50 & 0.23 & 30.54 \\
\hline 39 & Tymówka & III or less & 456.00 & 224.00 & 280.83 & 0.45 & 0.18 & 25.50 \\
\hline 40 & Paleśnianka & IV & 491.00 & 216.00 & 286.72 & 0.39 & 0.24 & 24.28 \\
\hline 41 & Brzozowianka & IV & 375.00 & 210.00 & 250.08 & 0.42 & 0.17 & 25.71 \\
\hline 42 & Siemiechowianka & III or less & 402.00 & 220.00 & 279.00 & 0.32 & 0.40 & 17.58 \\
\hline 43 & Więckówka & IV & 386.00 & 201.00 & 238.92 & 0.52 & 0.18 & 29.50 \\
\hline 44 & Jasienianka & IV & 479.00 & 287.00 & 344.29 & 0.33 & 0.39 & 20.16 \\
\hline 45 & Zborowianka & IV & 352.00 & 253.00 & 285.24 & 0.30 & 0.25 & 17.44 \\
\hline 46 & Jastrzębianka & V & 483.00 & 245.00 & 304.77 & 0.44 & 0.34 & 24.89 \\
\hline 47 & Rzepianka & IV & 369.00 & 238.00 & 271.53 & 0.46 & 0.22 & 24.40 \\
\hline 48 & Szwedka & VI & 448.00 & 222.00 & 271.53 & 0.53 & 0.20 & 28.08 \\
\hline 49 & Biała & VI & 777.00 & 183.00 & 309.64 & 0.47 & 0.29 & 28.68 \\
\hline \multirow[t]{4}{*}{50} & Wątok & IV & 315.00 & 197.00 & 236.41 & 0.32 & 0.32 & 16.60 \\
\hline & & & & & $\begin{array}{l}\text { min. } \\
\text { value }\end{array}$ & 0.62 & 0.63 & 33.03 \\
\hline & & & & & $\begin{array}{l}\text { max. } \\
\text { value }\end{array}$ & 0.10 & 0.09 & 7.34 \\
\hline & & & & & $\begin{array}{l}\text { mean } \\
\text { value }\end{array}$ & 0.34 & 0.31 & 20.06 \\
\hline
\end{tabular}

The calculated values of the three parameters $\left(C_{\max }, d l / L, C_{f}\right)$ have been compared using the 3D scatter plot correlation (Fig.5F).

The Hack's Stream Length ( $S L)$ Index is one of the techniques commonly used to identify areas experiencing rapid tectonic deformation (e.g.: Keller and Pinter, 1996; Badura et al., 2007; Doranti-Tiritan et al., 2014). The index allows to normalize the gradient values and to identify the anomalous knick-points in along the river.

The SL Index values are calculated for the equal stretches along the analyzed streams by the following formula:

$$
S L=S \cdot L
$$

$$
S=d H / d L
$$

where $S$ is inclination along the analyzed reach, $d L$ is the length of this reach, $d H$ is the difference of altitude between two points in the watercourse, and $L$ is the total length of the channel (Fig. 5G-I).

The $S L$ Index remains approximately constant along the graded streams and all the variations appear to be related to the tectonic and lithological controls (e.g. Lifton and Chase, 1992; Badura et al., 2007; DorantiTiritan et al., 2014). 


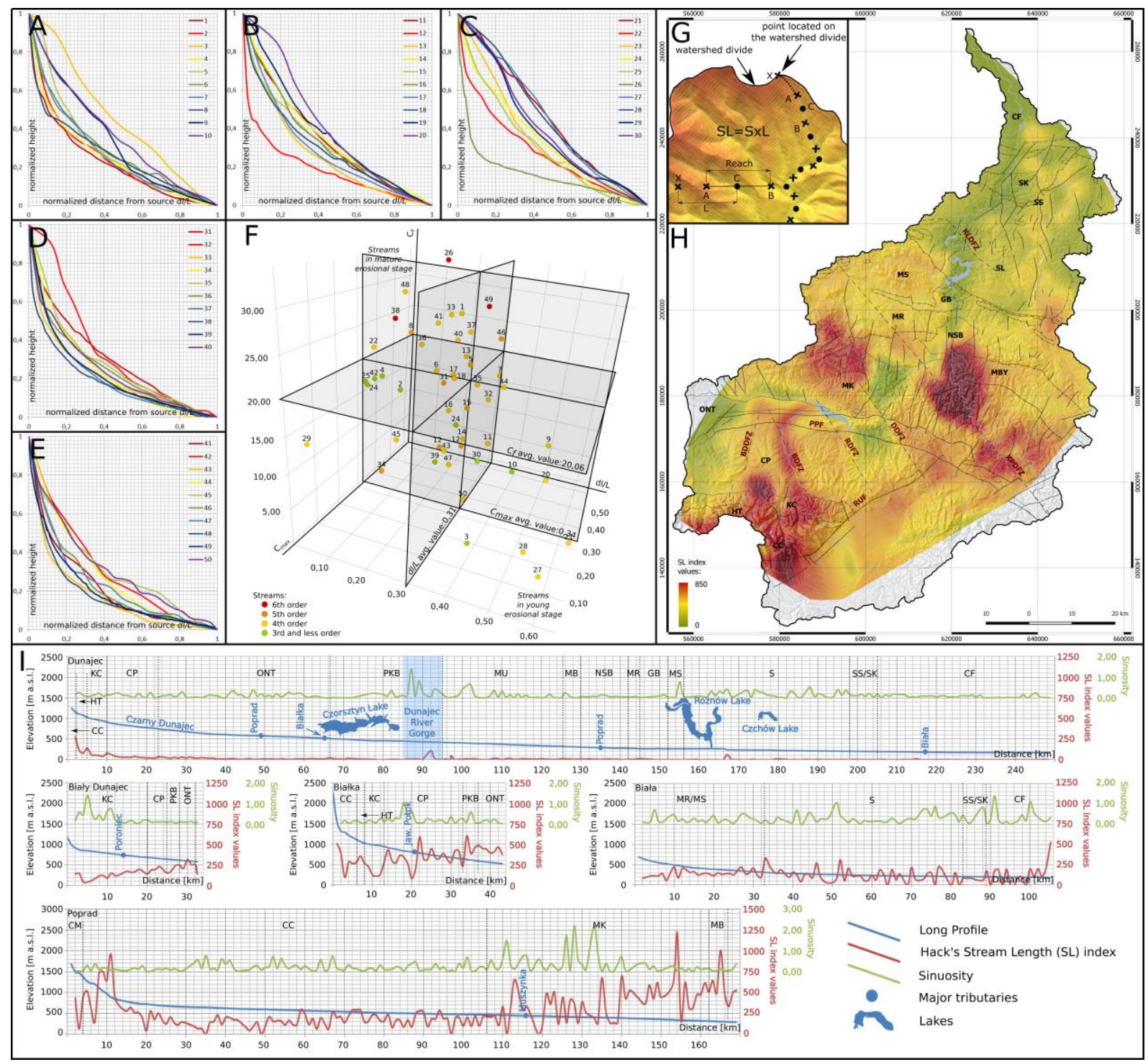

Fig.4. Streams morphometry analysis. A-E normalized long profiles of 50 analyzed streams; F - scatter plot of $C m a x, C f$ and $d L$ values calculated for 50 analyzed streams classified according to their order (Strahler, 1952); G - Hack's Slope-Length index (SL) concept: X - point on the watershed divide; $|\mathrm{AB}|$ - analyzed reach; C midpoint; $\mathrm{S}$ - slope inclination of the reach; $\mathrm{L}$ - length value for the analysis; $\mathrm{H}-\mathrm{SL}$ index values distribution within the researched area; I - long profiles of the main rivers (blue line): Dunajec River (including Czarny Dunajec), Biały Dunajec River, Białka River, Biała River and Poprad River. The distribution of Hack's StreamLength index values (red line) as well as the sinuosity index values (green line) is also included.

\section{Hypsometric analysis}

The analysis of the hypsometric parameters has been conducted based on the DETD2 data.The hypsometric integral $H I$ shows the distribution of the landmass volume remaining beneath or above the basal reference plane (Strahler, 1952; Schumm, 1956; Andreani et al. 2014). It can be calculated for a given area by using the equation:

\section{$H I=(H m e a n-H m i n) /(H m a x-H m i n)$}

with Hmean, Hmin and Hmax being the mean, minimum and maximum elevations of the analyzed area (Pike and Wilson, 1971; Andreani et al. 2014) 


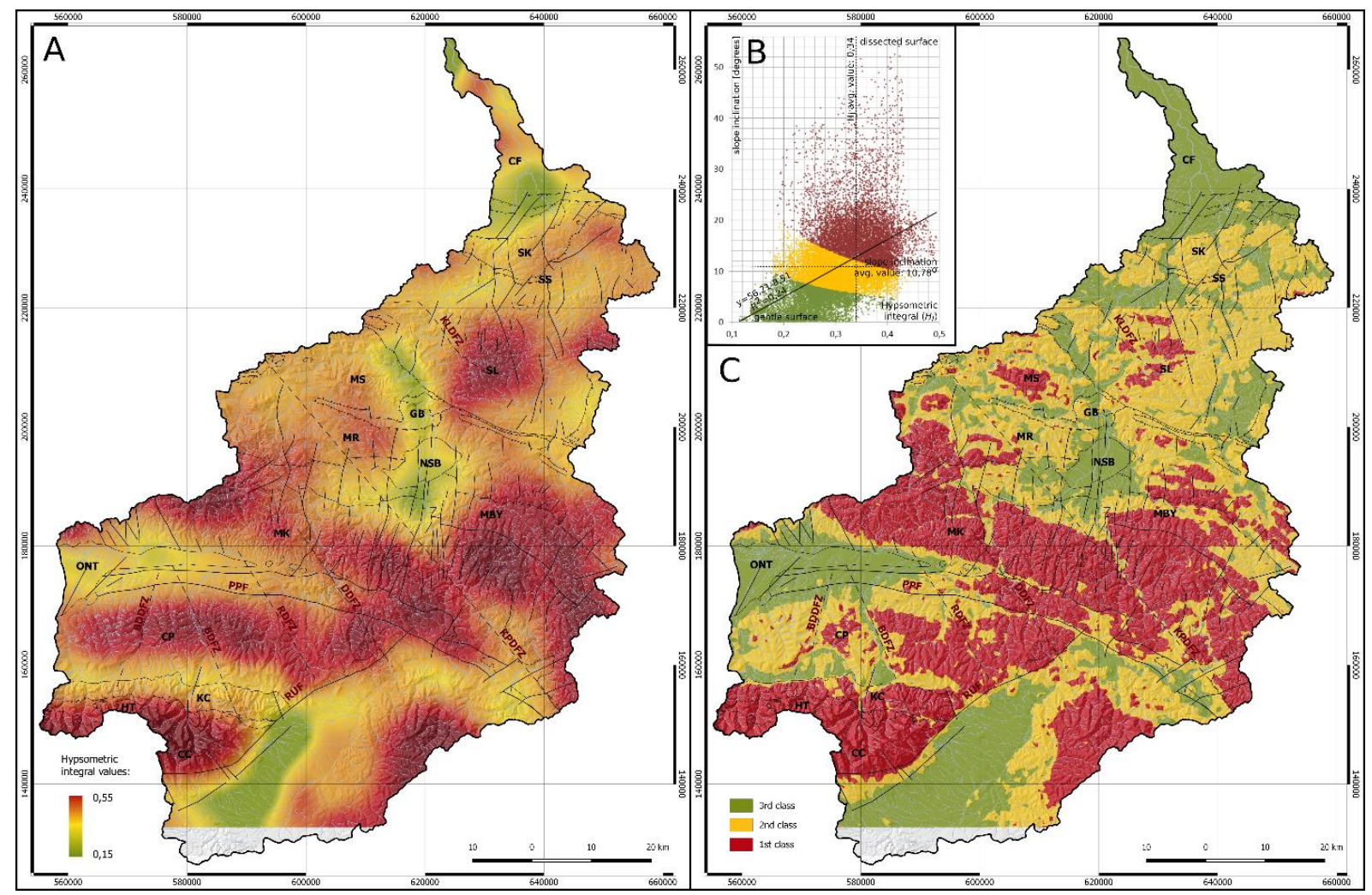

Fig.5. Hypsometric analysis. A - Map presents the values of Hypsometric Integral $H I$ values calculated using a $10 \mathrm{~km}$ moving window; B - Hypsometric Integral HI and slope inclination analysis - scatter plot of the slope inclination and Hypsometric Integral values; $\mathrm{C}$ - map presents the spatial distribution of 3 classes distinguished according to the scatter plot $\mathrm{B}$ against the background of the major tectonic features.

The hypsometric integral summarizes the relief of the researched area. Therefore, it is a good indicator of the erosional development and a useful tool to delineate the anomalous areas within the mountain range.

The HI values were calculated within a moving $1 \mathrm{~km}^{2}$ window. Then the values were interpolated to create the raster map (Fig.5).

\section{Isolongs analysis}

Maps of the isolongs (Fig.6A) give the possibility of estimating the relation between the tectonics and the valley order's growth quantitatively as it consists of the isolines of the valley lengths (Zuchiewicz, 2010). The highest values of the valley lengths are usually connected with the narrow tectonic basins, while the lowest ones characterize the uplifted areas. The isolong pattern is supposed to reflect mainly the buried uplifted areas. According to Zuchiewicz (2010), the degree of correlation between the tectonic maps and the isolongs maps might reach up to $85 \%$.

\section{Base-levels analysis}

The concept of the base-level was first defined by Powell in 1875 as, "a level below which the dry lands cannot be eroded". The local base levels can be defined according to different geological conditions across the regions.

The base-level maps express the relationship between the valley order and the topography (e.g. Zuchiewicz, 1981; Rączkowski et al, 1984; Fig.6B). The valley order refers to the relative position of the stream segments within the drainage basin network where the streams of similar orders are related to the similar geological events. Each base-level surface is related to a certain erosional stage and can be considered as a product of the erosionaltectonic events, especially the most recent ones. The base-level map can also be seen as a 


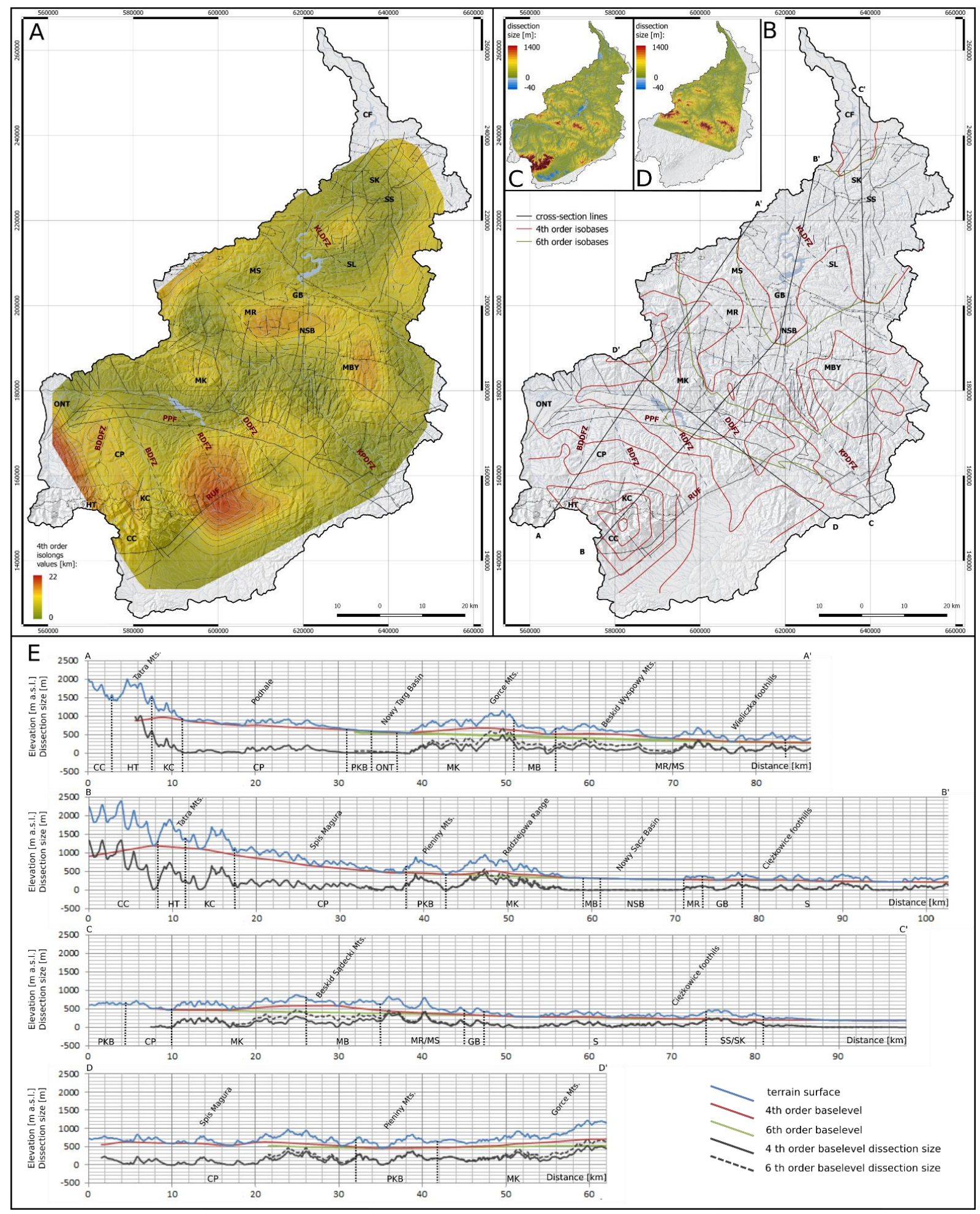

Fig.6. Isolongs and base-levels analysis. A $-4^{\text {th }}$ order isolongs map; B $-4^{\text {th }}$ and $6^{\text {th }}$ order isobases map; $\mathrm{C}-4^{\text {th }}$ order base-level erosional dissection map; D - $6^{\text {th }}$ order base-level erosional dissection map; E - base-level surfaces and erosional dissection size analysis along the cross-sections. 
"simplified" version of the original topographic surface, from which the "noise" of the low-order stream erosion has been removed (Zuchiewicz, 1981).

The order of the base-level is determined by the order of the considered valleys, e.g.: in the $2^{\text {nd }}$ order base-level all valleys, but the $1^{\text {st }}$ order, are considered (Zuchiewicz, 2010).

A series of base-level maps makes it possible to construct maps of differences among the surfaces of various orders, as well as, between the certain base-level and the terrain surface (Fig.6C, D). These kind of maps provide information about the size of the erosional dissection within the studied area during the period which lasted between the formation of the base-level surfaces.

\section{Basins morphometric analysis}

For this part of the study the $6^{\text {th }}$ to the $8^{\text {th }}$ order drainage basins (classified according to the Gravelius method; Gravelius, 1914) have been digitized from the hydrographic map of Poland at scale of 1: 50,000 and cross-checked with the shaded relief map ( sun azimuth $=315^{\circ}$, sun elevation angle $=40^{\circ}$ ) based on DTED 2 (by courtesy of ZGW WOGiT 2000) to perform the morphometric analysis.

As a result, 839 watersheds have been extracted including 95 drainage basins of the 6th order, 47 drainage basins of the $7^{\text {th }}$ order and 697 drainage basins of the $8^{\text {th }}$ order. Then their geometric parameters such as length $L$, total area $A$ (Horton, 1945), perimeter $P$ (Smith, 1950; Fig.8A) and the average width $W_{\text {mean }}$ (Brzezińska-Wójcik et al., 2010), as well as some more complex morphometric ratios have been calculated. The coefficients used in this paper are: Relief Ratio $R_{h}$ (Strahler, 1954), Relative Relief $R_{h p}$ (Melton, 1958), Circulatory Ratio $R_{k}$ (Miller, 1953), Basin Compactness $B_{c}$ (Engstrom, 1989), Elongation Ratio $R_{e}$ (Schumm, 1954), Form Ratio $R_{f}$ (Horton, 1945) and Lemniscate Coefficient $k$ (Chorley, 1971).
Relief ratio $R_{h}$ may be defined as the ratio of the maximum denivelation to the basins length (Strahler, 1954):

$$
R_{h}=\left(H_{\max }-H_{\min }\right) / L
$$

Relative relief $R_{h p}$ is the ratio of the maximum denivelation to the basins area (Melton, 1958):

$$
R_{h p}=\left(H_{\max }-H_{\min }\right) / A .
$$

Circulatory Ratio $R_{k}$ compares the area of the watershed with the circle whose perimeter is equal to that of the basin (Miller, 1953):

$$
R_{k}=4 \pi A / P^{2}
$$

Drainage basin compactness index $B_{c}$ can be defined as the ratio of the basin's perimeter to its area (Engstrom 1989):

$$
B_{c}=P / A .
$$

Elongation ratio $R_{e}$ is calculated as the ratio of the circle diameter, the area of which is equal to the area of a drainage basin, to the maximum basin length (Schumm, 1956; Eagleson, 1970; Brzezińska-Wójcik et al., 2010):

$$
R_{e}=2(A / \pi)^{0,5} / L
$$

The form ratio $R_{f}$ (Horton 1945) compares the outline of the drainage basin with a rectangle (Brzezińska-Wójcik et al., 2010):

$$
R_{f}=A / L^{2}
$$

It is significant that the value of the $R f$ coefficient decreases with the increase of the basin area (Eagleson, 1970; Gregory and Walling, 1973).

The drainage basins tend to show the $R_{h}$, $R_{h p}, R_{k}, B c, R_{e}$ and $R_{f}$ values seeking to 0 for the 
tectonically active areas and the values seeking to 1 for less active/inactive areas.

The lemniscate coefficient $k$ (Chorley, 1971) compares the basin with the shape of the lemniscate $\infty$ :

$$
k=\pi L^{2} / 4 A .
$$

The increase of the $k$ values indicates the increase of the tectonic activity of the watershed. The lemniscate coefficient is used less often than the indicators mentioned before. It adopts the values in very broad ranges depending on the diversity of the area in hypsometric and geological terms.

The calculated values of the morphometric coefficients have been normalized among the basins of each order. This allowed for recognition of the level of rejuvenation of the basins' morphology. The values were then interpolated to create the map of the relative rejuvenation level within the researched area (Fig.7B).

\section{Results}

\section{Slope aspect and lineaments analysis}

The slope aspect diagrams reveal the domination of SW, S and SE trending slopes. The N-S oriented symmetry axis is also clearly visible (Fig.2B).

750 lineaments have been extracted and analyzed based on the maps at scale of 1:500000 and another 3066 lineaments have been delineated based on the maps at scale of 1:100000 (Fig.2C). The rose diagram based on the 1:500000 lineaments suggests NNW-SSE and NW-SE as the two main structural directions. They coincide with the orientation of the major deep seated fault zones across the study area. The rose diagram based on the 1:100000 lineaments shows NW-SE as the major structural direction. The latitudinal (WE) direction as well as NE-SW seem to play secondary role. Latitudinal and sub-latitudinal orientations, which happen to coincide with the orientation of the most of the thrusts, are characteristic for the $\mathrm{W}$ part of the researched area, while the NW-SE trending lineaments related to the main fault structures are typical for the E part.

\section{Morphometric analysis of streams}

Ideally, the high concavity factor values and the maximum concavity values, located closer to the source, indicate concave upward streams closer to the equilibrium profile (Demoulin, 1998; Rãdoane et al., 2003; RuszkiczayRüdiger et al., 2009; Matoš et al., 2014). The values calculated within the study area are presented in the Table 1. Maximum concavity values vary between 0,10 and 0,62 , normalized distance from the source values vary between 0,09 and 0,63 and the concavity factor values vary between $7,34 \%$ and $33,03 \%$.

The streams of the similar orders are usually of a similar geological age (e.g. Zuchiewicz, 1981). The streams in the scatter plot have been classified according to the Strahler method to represent this relationship.

The equilibrium conditions (mature erosional stage) are related to the streams of the higher orders while the young erosional stage conditions tend to be related to the streams of the lower order. Among the streams of the $4^{\text {th }}$ and lower orders, the young erosional stage conditions are characteristic for the two groups of streams. The streams along the Kraków-Prešov Deep Fault Zone $(20,21,27,28,30)$ and the streams originating in the Tatra Mts. and their foreland, including the tributaries of the Czarny Dunajec river, the Biały Dunajec river, and the Białka river (3,7,9,10,11,14; Fig.3).

The SL Index has been calculated for the $1 \mathrm{~km}$-long stretches along the analyzed streams. The results have been presented on the map on the background of the major tectonic features (Fig.4H) and on the long profiles of the selected major rivers (Fig.4I). The values vary from 0 up to 850 , with the average value of 


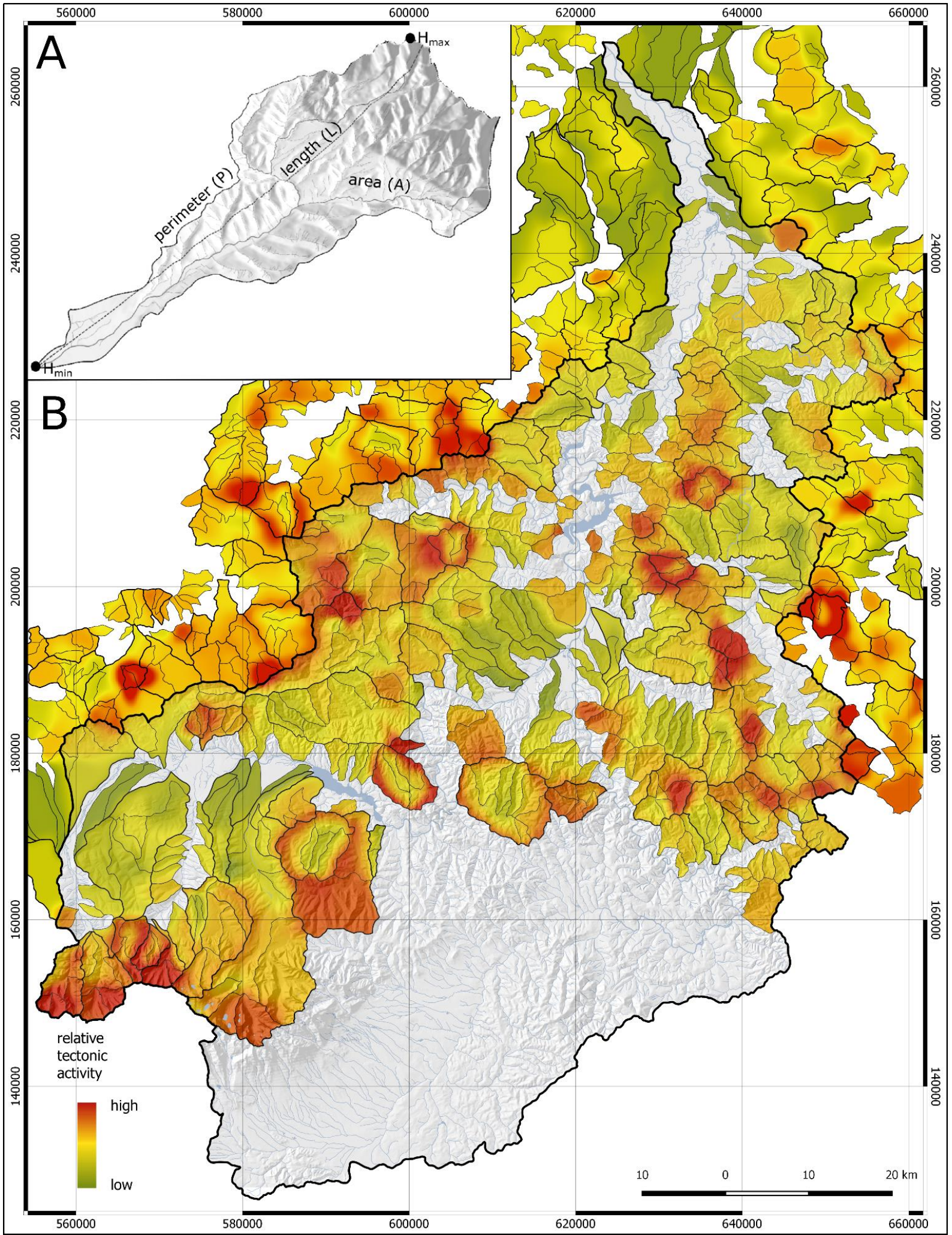

Fig.7. Relative tectonic activity analysis according to the morphometric parameters of the drainage basins. A scheme of the morphometric parameters of the drainage basins; B - spatial distribution of the relative tectonic activity values calculated for the $6^{\text {th }}$ to $8^{\text {th }}$ order drainage basins. 

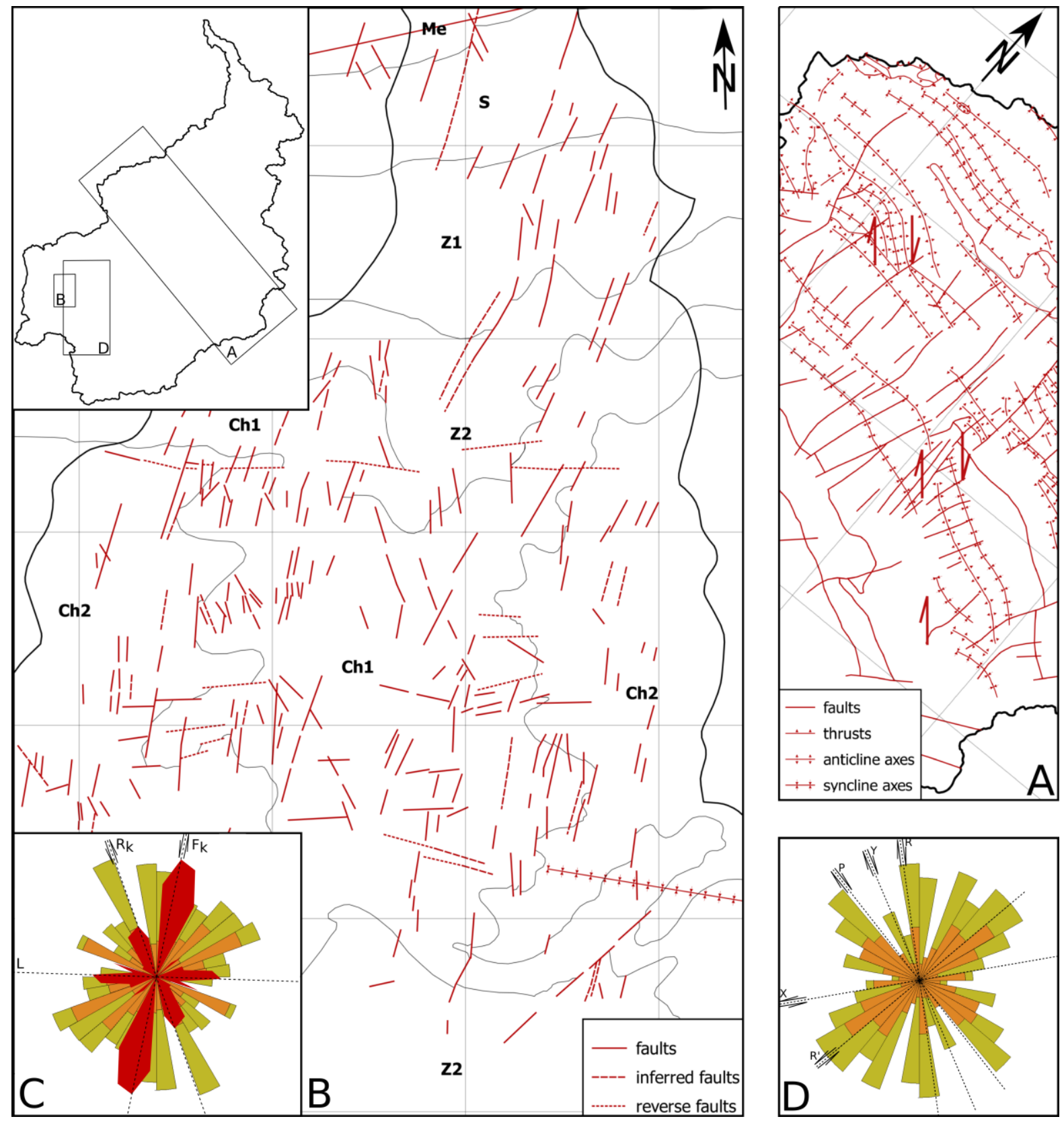

Fig.8. Morphotectonic analysis of the selected areas: A - sketch map of the Kraków-Prešov Deep Fault Zone area (Żaba, 1995; 1999; see Fig.1). Arrows represent the direction of the dislocation; B - geological sketch map of the Biały Dunajec Valley (Mastella et all, 2012 - modified): Ch2 - Upper Chochołów beds; Ch1 - Lower Chochołów beds; Z2 - Upper Zakopane beds; Z1 - Lower Zakopane beds; S - Szaflary beds; Me - Mesozoic and Paleogene of the Pieniny Klippen Belt (undivided); C - rose diagram of the faults (red; Mastella et all. 2012) and lineaments (orange - scale 1:100 000; green - scale 1:500 000); Fk, Rk, L - three classes of faults described by Mastella et all. (2012); D - rose diagram of the lineaments within the Białka drainage basin and the theoretical right-lateral simple shear model of the Białka Fault Zone (Wołosiewicz, 2016): Y - main fault; R Riedel synthetic shears; R' Riedel antithetic shears; P - secondary synthetic shears; X - complementary antithetic shears.

145. The highest values are related to the Sądecki Beskid range, along the Poprad river (Kraków-Presov Fault Zone; KPDFZ). Lesser positive anomalies are located in the Tatra Mts., particularly the Crystalline Massif and the area along the Cicha Woda river, as well 
as, the Gorce Mts. along the Ochotnica and the Kamienica Zabrzeska rivers. A major linear anomaly can be observed along the Białka river (the Białka Fault Zone; BDFZ).

SL values observed along the long profiles of the main rivers reveal the anomalies related to the following major tectonic features and boundaries: The High Tatra Units / the Križna Nappe boundary (the Białka, the Czarny Dunajec); the Northern boundary of the Tatra Mts. (the Zlin-Plavec lineament; the Białka, the Czarny Dunajec); the Peri-Pieniny Fault (the Białka), the Dunajec River Gorge (the Dunajec Fault Zone; the Dunajec).

\section{Hypsometric analysis}

Ideally, the low hypsometric integral values (concave hypsometric curves) should describe mature, tectonically stable, denuded areas. This type of area can be considered as dominated by fluvial erosion; the channel processes play a vital role there. The high HI values (convex hypsometric curves) should indicate young, unstable, actively uplifting areas. This kind of areas are usually dominated by the diffusive, mainly hill-slope processes (Willgoose and Hancock, 1998). More balanced, flattened Sshaped hypsometric curves with $H I$ values close to 0,50 , suggest relatively stable but still developing landscapes (Matos, 2014).

The highest HI values within the researched area can be observed in the Tatra Mts., Spiš-Gubałówka foothills, the Levoča Mts., the Pieniny Mts., the Gorce Mts., the Beskid Sądecki range, the Wyspowy Beskid range, and Rożnów foothills (Fig. 5A).

In order to distinguish the areas with a relative uplift from the areas with a relative subsidence, a scatter plot of HI values in relation to slope inclination values, has been used (Ruszkiczay-Rüdiger et al., 2009; Matos et al., 2014; Fig.5B). The three classes are distinguished based on the plot, allowing for the creation of an interpretational map (Fig.5C).
Class 1 comprises areas with dissected landscape having both high slope inclination values and high $H I$ values which correlate with high differential uplift rates and probable predominance of erosional processes.

Class 2 represents the areas with intermediate slope inclination and $H I$ values.

Class 3 is associated with low slope inclination values and low $H I$ values which indicate low values of uplift rates and a likely predominance of accumulation processes (Matos, 2014).

According to the analysis, the areas such as the Tatra Mts., Spiš Magura, the Levoča Mts., the Pieniny Mts., the Gorce Mts., and Beskid Sądecki range can be considered as the most tectonically active. The classified map image projects the pattern of the major tectonic units. Also, the major dislocations are clearly visible as anomalies.

\section{Isolongs analysis}

The analysis of the $4^{\text {th }}$ order isolongs reveals that the lowest values of stream lengths which are supposed to indicate the uplifted areas, are related to the axis of the Dunajec river valley. The local minima can be observed along the Białka Deep Fault Zone and along the Kraków-Prešov Deep Fault Zone (Fig. 6A).

\section{Base-levels analysis}

The highest concentration of $4^{\text {th }}$ order isobases can be observed within the area of the Tatra Mts. (Fig.6B).

The highest erosional dissection size can be observed within the Tatra Mts., the Gorce Mts., Beskid Sądecki range and Beskid Wyspowy (Island Beskid) range (Fig.6C; D; E). For the main tectonic units, the average values of dissection tend to rise toward the South (except the Orava-Nowy Targ Basin Area; Zuchiewicz, 1981; 1991; 2010; Wołosiewicz, 2016). 


\section{Basins morphometric analysis}

According to the relative analysis of the morphometric parameters of the watersheds, the most tectonically active areas are the Tatra Mts., the Wyspowy Beskid range, the Żywiecki Beskid range, the Gorce Mts., and the Saqdecki Beskid range, as well as, the Rożnów and Wiśnicz foothills. The areas of the relatively low rejuvenation are located within the Podhale region, especially in the Orava-Nowy Targ Basin, in the Nowy Sącz Basin, and within the Carpathian Foredeep area.

\section{Discussion}

Analysis of the tectonic sketch map shows that the dextral Krakow-Presov Fault Zone

(KPDFZ) influences the shape of the major tectonic structures including the main folds axes

(Fig.8A). The axes of the folds in the Mesozoic formations of the Outer Carpathians were dislocated along the fault zone seated within the Paleozoic basement which suggests the activity of this dislocation lasting beyond the Paleozoic era.

The geomorphological features of the drainage network within the researched area are very diverse. The lithology is the one of the most significant agents in the drainage system's development process (Klimaszewski, 1978). The morphology of the river valleys, has been also strongly influenced by the glaciers (Klimaszewski, 1988). However, it is believed that tectonics is the critical factor affecting the geomorphological features of the mountainous regions (Hantke and Scheidegger, 1999).

Several of the valleys that cut transversely through the mountain ranges are antecedent to the genesis of these ranges. However, the river action in such gorges is too small to keep up with the orogeny. The hydraulic bottom shearing stress in the rivers is approximately $100 \mathrm{kPa}$, while the shearing strength of rocks is approximately $10 \mathrm{MPa}$ (Hantke and Scheidegger, 1999). Thus, it can be concluded, that it wouldn't be possible for the river to erode through the rising mountains in a sawlike fashion. This is the evidence which proves that the tectonic features such as the shear zones, faults, and joints are the most significant factor in the genesis of mountain rivers as they allow them to overcome the uplift of the mountains.

The geometry of the drainage network in the studied area is also in close relationship with the tectonic structures. The main rivers such as the Biały Dunajec, the Czarny Dunajec, the Poprad, as well as, some segments of the Dunajec flow along the lines determined by the course of the major deep seated fault zones (Biały Dunajec fault BDDFZ, Białka fault BDFZ, Rieka fault RDFZ, Krakow-Presov deep fault zone KPDFZ). That relationship reflects the influence that the deep seated tectonic structures have on the geomorphological features of the landscape.

\section{Lineaments}

Using the aspect map for analysis of lineaments allows to mark the morphological edges precisely (Jordan, 2003). On the other hand, the multiple shaded relief maps analysis allows to objectify the study (e.g. Karnkowski and Ozimkowski, 2001).

NNW-SSE and NW-SE lineaments orientations are related to the major dextral structures (Biały Dunajec fault BDDFZ, Białka fault BDFZ, Rieka fault RDFZ, KrakowPresov deep fault zone KPDFZ), while the latitudinal (W-E) direction seems to be related to the major thrusts. Detailed investigation of the relationship between the orientation of the lineaments and the major deep seated tectonic features has revealed a strong correlation. The analysis of the lineaments within the Biały Dunajec watershed reveals that NNE-SSW maximum orientation coincides there with the left-lateral BDDFZ and the parallel mesoscale 
faults Fk (Fig.8B; C; Mastella et al., 2012). Also, the orientation of geologically related sinistral, NNW-SSE trending $R k$ faults that may be considered as Riedel synthetic shears $R$ (Riedel 1929; Mastella et al. 2012), is very well represented among the morphological structures.

The faults diagrams for the Białka Drainage Basin (Mastella et al. 1996) reveal the faults pattern related to the major dextral, NNW-SSE trending BDFZ, as well as, the related Riedel antithetic shears $R^{\prime}$. Lineaments delineated within the basin are mostly $\mathrm{N}-\mathrm{S}$, possibly related to the right-lateral Riedel synthetic shear structures (Wołosiewicz, 2016; Fig.8D).

\section{Base-level analysis}

The elevated areas are typically represented by the elongated positive forms on the differential maps (Fig. 6C; D.; the Tatra Mts., the Gorce Mts., Sądecki Beskid Range). Based on both the 4th (Early Quaternary?) and the 6th (Pliocene?) order of the base-level surfaces (Zuchiewicz, 1981), the diagram (Fig. 9) was developed to present the distribution of the erosional dissection size values calculated for the major tectonic units. The results obtained for the Inner Carpathian units, particularly the Tatra Mts., are characterized by the highest values of dissection size, as well as, very high dispersion of data which is caused by the valleys cutting deep in the uplifted areas. The ranges related to the unit of the Magura Nappe are also characterized by highly erosional dissection size values. The lowest values can be observed in the Orava-Nowy Targ basin and the Nowy Sacz basin. The data distribution is quite symmetrical for the cristalline basement and the Tatric Unit and it has a negative skew for all the other studied units which reflects the distribution of the less inclined/flat areas. The results obtained in the study confirm the general tendencies described by Zuchiewicz (1981).

\section{Morphometric analysis}

Some of the morphometric coefficients describing the drainage basins, as well as, some linear coefficients describing mountain fronts and the geometry of river valleys, are the parameters which can be used to illustrate the relationship between the drainage system and amplitudes of vertical crustal movements (Brzezińska-Wójcik et al., 2010; Zuchiewicz, 2010). In opposition to the methods such as precise leveling studies (e.g. Wyrzykowski, 1971; Makowska and Jaroszewski, 1987), or the radar interferometry analysis (Perski, 2008), the morphometric methods provide relative values rather than absolute results. That is why terms such as 'relative tectonic activity' or 'relative tectonic uplift' are commonly used (e.g. Brzezińska-Wójcik, 2010). However, the major advantage of using those indirect indicators of tectonic activity is the fact that the method can be used in the geologically heterogeneous system (Brzezińska-Wójcik et al., 2010).

\section{Hypsometric analysis}

The Hypsometric Integral indicates the erosional development of the area. However, it is possible for areas with very different geomorphic histories to have identical HI values. Similar-looking curves can be produced by complex interactions of climate, tectonism, sedimentation and rock resistance (Bishop et al., 2002). Thus, it is crucial to compare the results with other data. The comparison of the Hypsometric Integral diagram with the dissection size diagrams, as well as, the relative tectonic activity diagram based on the morphometric analysis of the drainage basins shows the high correlation of those indicators. (Fig.9). The highest relative tectonic activity with the low data dispersion is characteristic for the Tatra Mts. Also, the Magura Nappe units are characterized by the high activity but the data is less homogenous. 


\section{Conclusions}

The deep seated NW-SE oriented fault zones play a vital role in the geological architecture and morphology of the researched area. The development of the secondary fault structures was strictly determined by those dislocations. The manifestation of their activity can be observed as the deformations of some other tectonic structures along the main fault zones, especially the folds' axes (Fig. 9.). Also, the geometric and morphometric features of the drainage system were influenced by the activity of those deep structures.

There are significant differences in the morphological development within the researched area. The tectonic activity manifested as the level of morphological rejuvenation, clearly visible in the light of the morphometric parameters of the streams $\left(C_{\max }\right.$, $C f, S L)$ and the drainage basins $\left(R_{h}, R_{h p}, R_{k}, B_{c}\right.$, $\left.R_{e}, R_{f}, k\right)$, as well as, the Hypsometric Integral values, varies greatly between the tectonic units. This diversity is caused by both lithological and structural features of those units. The analysis of the base-level surfaces allows to investigate the history of those changes.

The base-level surfaces are difficult to date as they may represent the fragments of the mature landforms created in different time periods but are included within one base-level (Zuchiewicz, 2010). Despite the fact that they indicate the general tendencies in relative vertical movements between investigated units, the most active areas are related to the Tatra

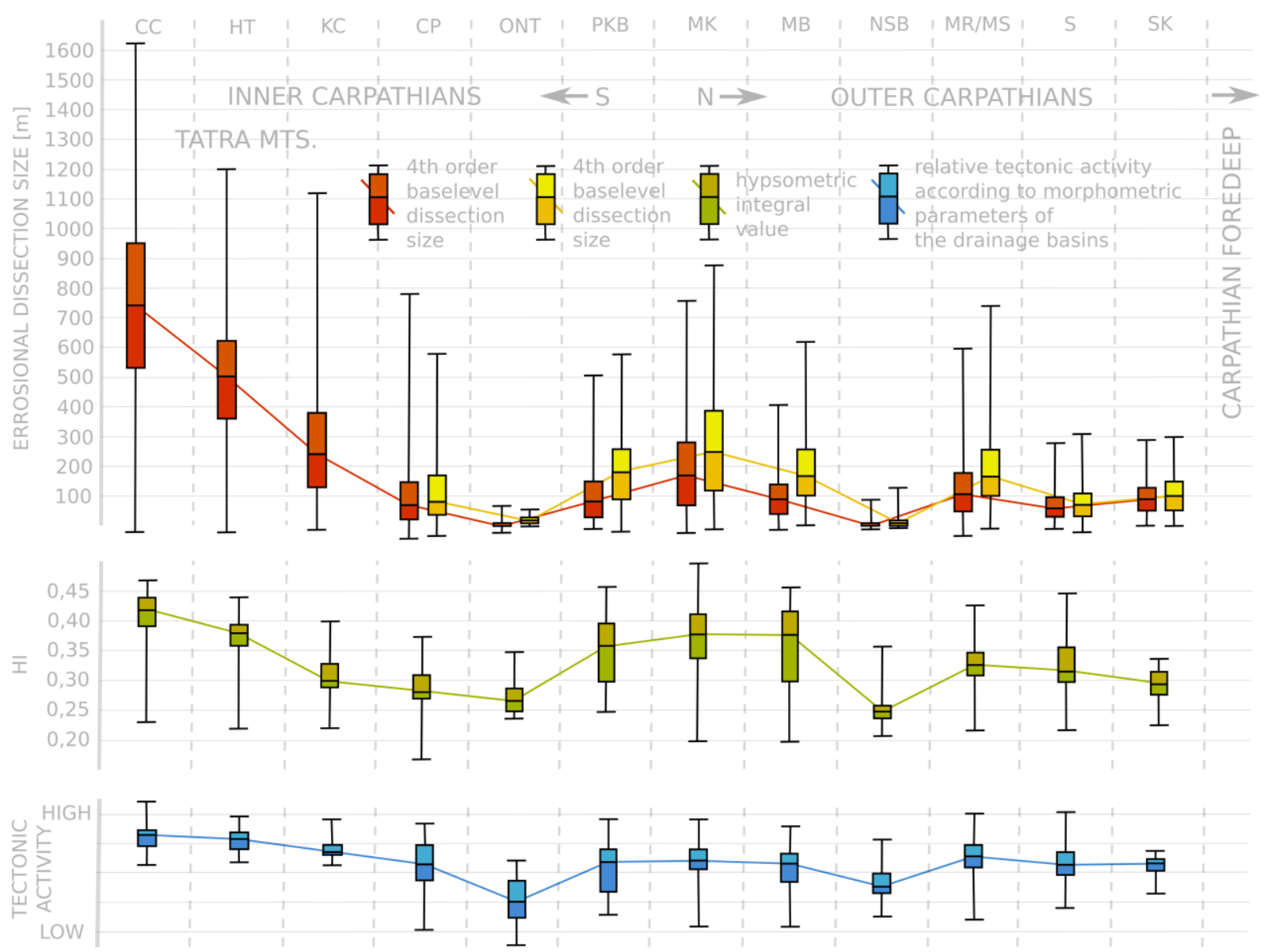

Fig.9. Diagram shows distribution of values of several indicators within various tectonic units across the researched area (see Fig. 1.): $4^{\text {th }}$ order base-level erosional dissection size (red); $6^{\text {th }}$ order base-level erosional dissection size (yellow); hypsometric integral values (green); relative tectonic activity according to morphometric parameters of the drainage basins (blue). 
Mts. especially their crystalline massif as well as the ranges of the Beskidy Mts. located within the Magura Nappe unit. Additionally, the zones along the major dislocations exhibit the features characteristic for the active areas including high concentration of the base-levels isolines, as well as, their curvy shape. The lowest values of the erosional dissection are characteristic for the areas of the molasse basins.

The morphometric studies combined with the other remote methods provide the stable and reliable set of results defining the geological and geomorphological features of the study area. Using various methods simultaneously allows to objectify the study on the given area.

The morphological evidence allows to suspect about the more detailed features of the structures such as the Kraków-Presov deep fault zone. Its activity seems to be responsible for the development of the secondary structures and the geometric features of the local drainage system which makes it the locally vital morphogenetic factor. The results of the remote morphometric analyses encourage to perform the further research based on the geophysical data as well as the structural studies.

\section{Acknowledgements}

I would like to thank Professor Jan Golonka for all his helpful suggestions, as well as, Professor Jerzy Żaba and Ryszard Chybiorz for their support. Thanks to the editors and reviewers in Contemporary Trends in Geoscience whose comments allowed for improvement of the article. Thanks to Katarzyna Bebenek and Klaudia Mierzejewska who provided the lingusitic correction.

\section{References}

Ahmed A. and Świerczewska A. (2013) Fractured clasts in Domański Wierch gravels (Oravic Basin) as the fault zone indicators. In: Neotectonics of Poland Lublin, 27-28.09.13. Conference materials: 6-7. 9 (in Polish).

Andreani, L. and Gloaguen, R. (2014) Geomorphic analysis of transient landscapes in the Sierra Madre de Chiapas and Maya Mountains (northern Central America): implications for the North American-Caribbean-Cocos plate boundary. Earth Surf. Dynam., 4, 71-102, 2016

Badura, J., Zuchiewicz, W., Štěpančiková, P., Przybylski, B., Kotny, B., Cacoń, S. (2007) The Sudetic Marginal Fault: a young morphotectonic feature at the NE margin of the Bohemian Massif, Central Europe. Acta Geodyn. Geomater., Vol. 4, No. 4 (148), 7-29.

Birkenmajer, K. (1965) The geology of Polish part of Pieniny Klippen Belt. Annales Societatis Geologorum Poloniae, 35: 327356.

Birkenmajer, K. (2003) Geological problems under study in the Pieniny Mountains, West Carpathians: a review. Pieniny Przyroda i Człowiek 8: 33-40

Bishop, M.P., Shroeder, J.F., Bonk, R., Olsenholler, J. (2002) Geomorphic change in high mountains: a western Himalayan perspective. Global and Planetary Change 32:311-329.

Bull, W.B. (1977) Tectonic geomorphology of the Mojave Desert. U.S. Geological Survey Contract Report 14-08-001-G-394. Office of Earthquakes, Volcanoes and Engineering, Menlo Park, California, 188 pp.

Bull, W.B. (1978) Geomorphic tectonic activity classes of the south front of the San Gabriel Mountains, California. U.S. Geological Survey Contract Report 14-08001-G-394. Office of Earthquakes, Volcanoes and Engineering, Menlo Park, California, 59 pp. 
Bull, W.B. (2007) Tectonic Geomorphology of Mountains. A New Approach to Paleoseismology. Blackwell Publishing, Malden, MA, $316 \mathrm{pp}$.

Bull, W.B., McFadden, L.D. (1977) Tectonic geomorphology north and south of the Garlock fault, California. In: Doehring, D. O. (ed.), Geomorphology in Arid Regions. Proceedings of the 8th Annual Geomorphology Symposium. State University of New York at Binghampton, 9: 115-138.

Buła Z., Jachowicz M., Żaba J. (1997) Principal characteristics of the Upper Silesian Block and Małopolska Block border zone (Southern Poland). Geol. Magazine 134/5: 669-677.

Buła Z. (2000) Lower paleozoic of the Upper Silesia and Western part of the Małopolska Block. Prace Państwowego Instytutu Geologicznego 171: 1-63.

Buła Z., Habryn R. (2008) Geologicalstructural atlas of the paleozoic basement of the Outer Carpathians and Carpathian Foredeep. PGI, Warsaw, 2008.

Buła, Z. and Kotas, A. (1994) Mapa geologiczno-strukturalna utworów karbonu produktywnego. 1:100000, w: Atlas Geologiczny GZW. Część III, wyd. PIG, Warsaw 1994

Burbank, D. W. (1992) Causes of recent Himalayan uplift deduced from deposited patterns in the Ganges basin: Nature, v. 357 , p. $680-683$.

Burchart, J. (1972) Fission-track age determinations of accessory apatite from the tatra Mountains, Poland, Earth Planet. Sci. Lettr. 15: 418-422.

Brzezińska-Wójcik, T., Chabudziński, Ł., Gawrysiak, L. (2010) Neotectonic mobility of the Roztocze region, Ukrainian part, Central Europe: insights from morphometric studies. Annales Societatis Geologorum Poloniae, 80: 167-183.

Chorley, R. J. (1971) The drainage basin as a funda mental geomorphic unit. In: Chorley,
R. J. (ed.), Introduction to Physical Hydrology. Methuen, London: 37-59.

Doranti-Tiritan, C., Christian Hackspacher, P., Henrique de Souza, D., Siqueira-Ribeiro, M.C., (2014) The Use of the Stream Length-Gradient Index in Morphotectonic Analysis of Drainage Basins in Poços de Caldas Plateau, SE Brazil International Journal of Geosciences, 2014, 5, 13831394.

Demoulin, A. (1998) Testing the tectonic significance of some parameters of longitudinal river profiles: the case of the Ardenne (Belgum, NW Europe). Geomorphology 241998 189-208.

Eagleson, P.S. (1970) Dynamic Hydrology. McGraw-Hill Book Company, New York, $462 \mathrm{pp}$.

Frankel, K., Pazzaglia, F. J. (2005) Tectonic geomorphology, drainage basin metrics, and active mountain fronts. Geografia Fisica and Dinamica Quaternaria, v. 28, p. 7-21.

Gaidzik, K., Ramírez-Herrera, M.T. (2016), Geomorphic indices and relative tectonic uplift in the Guerrero sector of the Mexican forearc, Geoscience Frontiers 8: 885-902.

Golonka, J., Aleksandrowski, P., Aubrecht, M., Chowaniec, J, Chrustek, M., Cieszkowski, M., Florek, R., Gawęda, A., Jarosiński, M., Kępińska, B., Krobicki, M., Lefeld, J., Lewandowski, M., Marko, F., Michalik, M., Oszczypko, N., Picha, F., Potfaj, M., Słaby, E., Ślączka, A., Stefaniuk, M., Uchman, A. \& Andrzej Żelaźniewicz, A. (2005) Orava Deep Drilling Project and the Post Paleogene tectonics of the Carpathians. Annales Societatis Geologorum Poloniae, 75: 211-248.

Golonka, J., Pietsch, K., Marzec, P., Stefaniuk, M., Waśkowska, A. \& Cieszkowski, M. (2009) Tectonics of the western part of the Polish Outer Carpathians . Geodynamica Acta 22(1-2): 81-97. 
Golonka, J. Pietsch, K. \& Marzec P. (2011) Structure and plate tectonic evolution of the northern Outer Carpathians. In: Closson.D. (Ed.) Tectonics.. INTECH, Rijeka, Croatia. pp. 65-92.

Golonka J., Krobicki M., Waśkowska A., Cieszkowski M., Ślączka A. (2015) Olistostromes of the Pieniny Klippen Belt, Northern Carpathians. Geological Magazine, 152: 269-286.

Guterch, B. (2009) Seismicity in Poland in the light of historical records (in Polish with English summary). Przegląd Geologiczny, 57: 513-520,

Gravelius, H. (1914) Grundrifi der gesamten Gewcisserkunde. Band I Flufikunde (Compendium of Hydrology, Vol. I. Rivers, in German). Goschen, Berlin

Gregory, K.J., Walling, D.E. (1973) Drainage Basin Form and Process. A Geomorphological Approach. Edward Arnold. Ltd., London, 456 pp.

Hantke, R., Scheidegger, A.E. (1999) Tectonic predesign in geomorphology. Lecture Notes in Earth Sciences, 78: 251-266.

Hobbs, H. (1904) Lineaments of the Atlantic Border region. GSA Bulletin, 15: 483-506.

Horton, R.E. (1945) Erosional development of streams and their drainage basins; hydrophysical approach to quantitative morphology. GSA Buletin, 56: 275-370.

Jaroszewski, W. (1965) Ridge trenches in Tatra Mts. ASGP Vol. 35, 2: 163-171(in Polish with French summary)

Jordan,G. (2003) Morphometric analysis and tectonic interpretation of digital terrain data: a case study. Earth Surf. Process. Landforms 28, 807-822

Jurewicz, E. (2005) Geodynamic evolution of the Tatra Mts. and the Pieniny Klippen Belt (Western Carpathians): problems and comments. Acta Geologica Polonica, 55: 295-338

Jurewicz, E., Hecman, H., Nejbert, K. (2007) Flowstone-like calcite in the andesite of Jarmuta Mt. - dating the Holocene tectonic activity in the vicinity of Szczawnica (Magura Nappe, Outer Carpathians, Poland) Acta Geologica Polonica, Vol. 57 (2007), No. 2, pp. 187-204

Karnkowski, P.H., Ozimkowski W. (2001) Multi-coverage geological interpretation of satellite images: an overview with some examples from southern Poland (in Polish with English summary). Przegląd Geologiczny, 49: 1067-1072.

Keller, E. A. and Pinter, N. (1996) Active tectonics: Earthquakes, Uplift and Landscapes.Prentice Hall, New Jersey.

Kirby, E., Whipple, K., (2001) Quantifying differential rock-uplift rates via stream profile analysis. Geology 29 (5): 415-418.

Korup, O. (2006) Rock-Slope Failure and the River Long Profile. Geology, 34, 45-48.

Klimaszewski, M. (1978) Geomorphology (in Polish). PWN Warszawa.

Klimaszewski, M. (1988) Landforms of the Polish Tatra Mts (in Polish). PWN Warszawa.

Krobicki, M. and Golonka, J. (2008) Geotouristical values of the Pieniny Klippen Belt and Tatra Mountains regions (Poland). Przegląd Geologiczny, 56, 8/1: 670-679.

Krobicki, M., Golonka, J., Ślączka, A. (2012) The Carpathians - Menilite Shale as the main oil source in the Carpathians : field trip, leaders: Michał Krobicki, Jan Golonka ; with Contribution of Andrzej Ślączka In: GeoShale 2012 : recent advances in geology of fine-grained sediments : international conference : 14-16 May 2012, Warsaw, Poland : book of abstracts, field trip guidebook. Warsaw : Polish Geological Institute - National Research Institute: 195-233.

Kromuszczyńska, O., Mège, D. (2014), Ornak (Tatra Mountains) as a terrestrial analogue for Martian deep-seated gravitational spreading (sackung), ESA MPSE 2014 Conference Abstracts, C25 
Lifton, N.A. and Chase, C.G. (1992) Tectonic, Climatic and Lithologic Influences on Landscape Fractal Dimensions and Hypsometry: Implications of Landscape Evolution in the San Gabriel Mountains, California. Geomorphology, 5, 77-114.

Mahmood S. A., Gloaguen R. (2012) Appraisal of active tectonics in Hindu Kush: Insights from DEM derived geomorphic indices and drainage analysis. Geoscience Frontiers 3: 407-428

Mahel, M. (Ed.) (1974) Tectonics of the Carpathian-Balcan regions. Geological Institute Dionyza Stura, Bratislava, 454p.

Mastella L., Konon, A., Marsal, T. (1996) Tectonics of the Podhale flysch in Białka Valley. Prz. Geol., 44: 1189-1194 (in Polish with English summary)

Mastella, L., Ludwiniak, M., Klimkiewicz, D. (2012) Geology of the Biały Dunajec Valley (Podhale region, S Poland). Prz. Geol., 60: 496-505 (in Polish with English summary)

Makowska, A., Jaroszewski, W. (1987) On present vertical movements in Tatra Mts and Podhale (in Polish with English summary). Przegląd Geologiczny, 35: 506511.

Michałowicz, M., Malik, I., Wistuba, M. (2014) Dendrochronological records of small earthquakes recorded in Podhale region (southern Poland; in Polish with English summary). Studies and Materials of CEPL in Rogów. R.16. 40/3/2014

Miller, V. C. (1953) A Quantitative Geomorphic Study of Drainage Basin Characteristics in the Clinch Mountain Area, Virginia and Tennessee. ONR Technical Report 3, Project No. 271-030. New York, Columbia University, 51pp.

Melton M.A. (1958) Correlation structure of morphometric properties of drainage systems and their controlling agents. Journal of Geology 66: 442-460.

Pánek, T., Mentlík, P., Ditchburn, B., Zondervan, A., Norton, K., and Hradecký,
J., 2015, Are sackungen diagnostic features of (de)glaciated mountains? Geomorphology, v. 248 , p. 396-410, doi: 10.1016/j.geomorph.2015.07.022.

Pérez-Peña J.V., Azor A., Azañón J.M., Keller E.A. (2010) Active tectonics in the Sierra Nevada (Betic Cordillera, SE Spain): Insights from geomorphic indexes and drainage pattern analysis. Geomorphology 119(1-2): 74-87

Perski, Z. (2008) Recent tectonic activity of the Tatra Mts and Podhale (Poland) studied by InSAR and PSInSAR. Przegląd Geologiczny, 56: 1082-1086.

Pike, R.J. (2000) Geomorphometry - diversity in quantitative surface analysis. Progress in Physical Geography, 24: 1-20.

Pike, R.J. (2002) A bibliography of Terrain Modeling (Geomorphometry), the Quantitative Representation of Topography - supplement 4.0. Open-File Report 02465. U.S. Geological Survey, Denver, 158pp.

Pike. R. I., and Wilson, S. E. (1971) Elevationrelief ratio, Hypsometric integral and geomorphic area altitude analysis. Geol. Soc. Am. Bull., v. 82, p. 1079-1084.

Powell, J.W., (1875) Exploration of the Colorado River of the West. Washington, D.C., U.S. Government Printing Office, $291 \mathrm{pp}$.

Rãdoane, M., Rãdoane, N., Dimitriu, D. (2003) Geomorphological evolution of longitudinal river profiles in the Carpathians. Geomorphology 50 (2003) 293-306

Rączkowski, W., Wójcik, A., and Zuchiewicz, W. (1984) Late Neogene Quaternary tectonics of the Polish Carpathians in the light of neotectonic mapping: Tectonophysics, v. 108 (1-2): 51-69.

Rączkowski, W. (2007) Landslide hazard in the Polish Flysch Carpathians. Studia Geomorphologica Carpatho-Balcanica: Landform evolution in mountain areas, v. XLI: 61-75. 
Riedel, W. (1929) Zur Mechanik Geologischer Brucherscheinungen. Zentral-blatt fur Mineralogie, Geologie und Paleontologie B, 354-368. (in Geman)

Ruszkiczay-Rüdiger, Z., Fodor, L., Horváth, E., Telbisz, T. (2009) Discrimination of fluvial, eolian and neotectonic features in a low hilly landscape: A DEM-based morphotectonic analysis in the Central Pannonian Basin, Hungary. Geomorphology 104 (2009) 203-217.

Schumm, S.A., 1956. Evolution of drainage systems and slopes in badlands at Perth Amboy. New Jersey. Bulletin of the Geological Society of America 67(5): 597646.

Schenk, V., Schenkova, Z., Kottnauer, P., Guterch, B., and Labak, P. (2001) Earthquake hazards maps for the Czech Republic, Poland and Slovakia. Acta Geoph. Pol., 49, 3: 287-302.

Smith, K.G. (1950) Standards for grading texture of erosional topography. American Journal of Science, 248: 655-668.

Snyder, N.P., Whipple, K.X. Tucker, G.E., Merritts, D.J. (2000) Landscape response to tectonic forcing: Digital elevation model analysis of stream profiles in the Mendocino triple junction region, northern California. Geological Society of America Bulletin 2000;112;1250-1263

Szczygieł, J., 2015, Quaternary faulting in the Tatra Mountains, evidence from cave morphology and fault-slip analysis: Geologica Carpathica, v. 66, p. 245-254, doi: 10.1515/geoca-2015-0023.

Ślączka A. and Kaminski M. A. (1998) A Guidebook to excursions in the Polish Carpathians: Field Trips for Geoscientists. Grzybowski Foundation Special Publication, 6, 1-173.

Willgoose, G., and G. Hancock (1998), Revisiting the hypsometric curve as an indicator of form and process in transportlimited catchment, Earth Surf. Processes Landforms, 23(7), $611-623$
Wołosiewicz, B. (2016) Morphotectonic control of the Białka drainage basin (Central Carpathians): Insights from DEM and morphometric analysis. Contemp.Trends.Geosci., 5(1), 61-82.

Wyrzykowski T. (1971) The map of absolute speed of recent vertical movements of the crust in Poland. Państwowe Przedsiębiorstwo Wydawnictw Kartograficznych, Warszawa

Zuchiewicz, W. (1981) Morphotectonic methods applied to the morphostructural analysis of mountainous topography (Polish Western Carpathians). Annales Societatis Geologorum Poloniae, 51 (1-2): 99-116, Kraków.

Zuchiewicz, W. (1999) Morphometric techniques as a tool in neotectonic studies of the Polish Carpathians (southern Poland) (in Polish with English summary). Przegląd Geologiczny, 47: 851-854.

Zuchiewicz, W. (2010) Neotectonics of Polish Carpathians and their foredeep (in Polish with English summary). Wydawnictwa AGH.

Tokarski, A.K., Zuchciewicz, W. 1998 Fractured clasts in the Domañski Wierch series. Contribution to structural evolution of the Orawa Basin (Carpathians, Poland) during Neogene through Quaternary times. Prz. Geol., 46, 1: 62-66.

Żaba, J. (1995) Strike-slip faults at the edge zone of Upper Silesia and Małopolska Blocks (Southern Poland). Przegląd Geologiczny, 43: 838-842

Żaba, J. (1999) The structural evolution of Lower Palaeozoic succession in the Upper Silesia Block and Małopolska Block border zone (southern Poland). Prace Państwowego Instytutu Geologicznego Vol. 166: 5-162.

Żelaźniewicz, A., Aleksandrowski, P., Buła, Z., Karnkowski, P. H., Konon, A., Ślączka, A., Żaba, J., Żytko, K. (2011) Tectonic regionalization of Poland (in Polish). 
Komitet Nauk Geologicznych PAN,

Wrocław . 